\title{
Suspended solids and bacteria removal mechanisms in ceramic filter and pervious concrete filter: a review
}

\author{
Ekha Yogafanny Boulven ${ }^{1,2 *}$, Radianta Triatmadja ${ }^{1}$, Budi Kamulyan ${ }^{1}$, Fatchan Nurrochmad $^{1}$, and Intan Supraba ${ }^{1}$ \\ ${ }^{1}$ Civil and Environmental Engineering Department, Faculty of Engineering, Gadjah Mada University, Yogyakarta, Indonesia \\ ${ }^{2}$ Environmental Engineering Department, Faculty of Mineral Technology, University of Pembangunan Nasional "Veteran" \\ Yogyakarta, Indonesia
}

\begin{abstract}
The need for drinking water with affordable access is increasing nowadays. The poor water quality problems can be solved by several water treatment methods, i.e. ceramic filter $(\mathrm{CF})$ and pervious concrete filter (PCF). Those two mentioned technologies work based on the pores that exist within the filter. This study aimed to review (1) the influence of the material composition of the CF and PCF on hydraulic characteristics (porosity, permeability, pore size, pore structure, pore connectivity/ distribution) and its removal effectiveness, and (2) the removal mechanisms of suspended solids and bacteria based on its hydraulic characteristics. The study reviewed 45 literature, including books, reports, and published articles. The type, mineral, and sources of clay and the type, shape, proportion, and size of combustible materials on $\mathrm{CF}$ will affect its hydraulic characteristic. The shape, size, and type of aggregate, the ratio of water to cement, and the ratio of aggregate to cement on PCF will affect its hydraulic characteristics. The removal mechanisms of suspended solids are straining on the surface and trapping on the deadlocked pores. On the other hand, the bacteria removal mechanisms strain the bacteria in the dirt layer and trap the bacteria in the pores.
\end{abstract}

\section{Introduction}

The need for drinking water with affordable access is increasing nowadays, especially in developing countries and rural-remote areas where piped drinking water is not accessible. The current Covid-19 pandemic forces us to improve our resilience and immune system by increasing access to health services and vaccinations and basic hygiene and sanitation [1]. In developing countries, there are some ways to get water. Often, once the water sources are found, it is contaminated, especially by suspended solid and pathogens; hence it is not suitable for drinking water.

People applied several water treatment methods to solve a poor water quality, especially for decentralized water treatment systems in rural areas. A decentralized water treatment system is a water treatment that does not require a piping network so that it is considered to be able to overcome the problems of topographic and remote area barriers in the supply of clean water in developing countries [2,3]. This system consists of point-of-use and point-of-entry. A point-of-use system is a water treatment system that is carried out right before the water is used. Meanwhile, point-of-entry is a water treatment system carried out before water enters the household water system [4-6]. Some of the technologies used in point-of-use systems are chlorination, coagulation, solar disinfection, ceramic water filter, bio-sand filter [7], membrane filtration, fibre/fabrics filter $[3,8,9]$, and intermittent slow sand filtration [10-13]. Moreover, a new-promising technology called pervious concrete filter (PCF) can be used to reduce turbidity from the water reaching $95 \%$ efficiency [14].

Ceramic filter (CF) is a point-of-use technology that is widely used in developing countries. CF is made from a combination of clay and combustible materials such as rice husks, sawdust, coffee husks, and peanut husks [7]. The pores in the CF come from combustible organic matter that burns during the combustion process. The type and size of combustible material and the mixing process will affect the pore size, pore distribution, porosity, and permeability of the filter. These pores will drain the water and trap the contaminant from the contaminated water. This technology has been proven successful in reducing bacteria reaching $>99 \%$ or $>2$ LRV [7,15,16], viruses [17], protozoa [18], organic and inorganic compounds [19]. Unfortunately, high energy is needed reaching $900{ }^{\circ} \mathrm{C}-1000{ }^{\circ} \mathrm{C}$ in the ceramic firing process.

Pervious concrete filter (PCF) is one of the concrete applications in water purification. This technology is made from a mixture of sand and cement in a specific ratio, with no heat energy needed. The pores within the PCF are derived from the proper mix design composition of sand, cement, and water. This composition will affect the porosity, permeability, pore size, and pore distribution formed in the filter. This filter utilizes the pores in the concrete to drain water while holding the impurities that will remove from the

\footnotetext{
* Corresponding author: ekha.yogafanny@mail.ugm.ac.id
} 
contaminated water. PCF can reduce turbidity in water up to $95 \%$ and E.Coli bacteria up to $98.71 \%$ or $\log$ Removal Value (LRC) $=2$ [14,20-22], especially with a finer sand composition.

Those two mentioned technologies work based on the pores that exist within the filter. The hydraulic characteristics, i.e. porosity and permeability, play an essential role in increasing the efficiency of those filters in reducing the contaminants. Besides, the pore size, pore distribution, and the open connection between pores also affect the effectiveness of those two technologies. The different hydraulic characteristics formed on these two technologies cause the removal effectiveness to vary due to other particle removal mechanisms. The pore size, the permeability, the material used in the filter will affect the particle removal mechanisms. Understanding this relationship will improve the development of these two technologies as filters, especially for the PCF - new technology in a water filter.

This paper reviews (1) the influence of material composed of the CF and PCF on hydraulic characteristics (porosity, permeability, pore size, etc.) and its removal effectiveness, and (2) the removal mechanisms of suspended solids and bacteria based on its hydraulic characteristics.

\section{Research methods}

The method applied in this study is a literature review based on 45 works of literature, including books, reports, and published articles. The review consists of identifying the hydraulic characteristics based on the material composition of $\mathrm{CF}$ and $\mathrm{PCF}$ and its removal effectiveness. Moreover, the identification of suspended solids and bacteria removal mechanisms is also conducted according to its hydraulic characteristics.

\section{Result and discussion}

\subsection{Material composition and production}

\subsubsection{Ceramic filter}

The primary material used to make ceramic water filters (CF) is clay. Clay has its characteristics depending on the location of the quarry. Yakub et.al. (2013) made the $\mathrm{CF}$ from a mixture of clay (Cedar Heights Redart Airfloated Clay, Pittsburgh, PA) and sawdust ( $80 \%$ of oak and $20 \%$ of cedar) [23]. The clay is then mill and sieved through a 30 mesh or about $0.55 \mathrm{~mm}$ opening. This step is taken to ensure no non-clay particles such as sand or organic matter [24]. The composition of clay is observed by X-ray fluorescence (XRF) analysis.

The combustible material must be added to clay to produce the pores so that the water can flow through and the contaminant can be trapped in it. The combustible material consists of sawdust, rice husks, agriculture byproducts [7,25], and other organic materials such as coffee and peanut husks [24]. This organic material will burn during the combustion process and will leave pores in the ceramic. The size and proportion of the combustible material plays a significant role in the formation of pores and thus impacts the flow rate and removal efficiency.

Making ceramics filters begins with the preparation of the materials (clay and combustible material). The proportions of these two ingredients are arranged in such a way, for example, 50:50, 65:35, to 75:25. These two materials are milled and sieved according to the expected sizes, for example, a 30 -mesh $(0.55 \mathrm{~mm})$ size for both clay and combustible material or sieved the sawdust as combustible material by $35-1.000$ mesh of size [23]. After the fixed composition is ready, the mixing process is done manually or using a machine by pouring the water into it [26].

After the dough is finished, the next step is moulding into the expected shape; usually, the flowerpot shape presents in Figure 1 by pressing it according to the desired shape and thickness. The filter that has been formed is then air-dried. The next step is firing the filter in the kiln. The firing process of the filter consists of seven stages; they are (1) air drying at $19^{\circ} \mathrm{C}-25^{\circ} \mathrm{C}, 59 \%$ of humidity, 15 days, (2) water smoking at $20^{\circ} \mathrm{C}-$ $120^{\circ} \mathrm{C}$, (3) decomposition at $120^{\circ} \mathrm{C}-350^{\circ} \mathrm{C}$, (4) burnout combusts at $350^{\circ} \mathrm{C}-450^{\circ} \mathrm{C}$, (5) ceramic change at $350^{\circ} \mathrm{C}-700^{\circ} \mathrm{C},(6)$ carbon burns out at $700^{\circ} \mathrm{C}-900^{\circ} \mathrm{C}$, (7) vitrification at $<1000^{\circ} \mathrm{C}[7,27]$. The summary of material composition and production of two filters is given in Table 1.

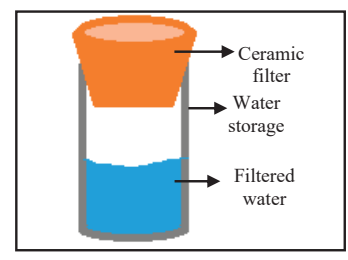

Fig. 1. Frustum shape or flower pot shape ceramic filter.

\subsubsection{Pervious concrete filter}

Pervious concrete is porous concrete that has high permeability and low compressive strength. This pervious concrete can be used as a filter to purify the water, so it is then called a pervious concrete filter (PCF). PCF is made from a mixture of sand (aggregate), cement, and water with a specific composition that causes pores in the PCF. PCF applications in terms of water treatment have been studied, resulting in filter effectiveness in reducing turbidity by $95 \%$ and bacteria by $98.7 \%$ [14,20-22].

The success of the use of PCF for water treatment purposes is largely determined by the hydraulic characteristics of the PCF, which is formed by a mixture of sand, cement, and water. The smaller the size of the sand used, the smaller the pore size that will form in it. The greater the ratio of sand and cement, the greater the porosity of the PCF will be. The size of the sand used varies from $1-2 \mathrm{~mm}$ [14], $2.36-13.2 \mathrm{~mm} \mathrm{[28],} 5$ - 10 $\mathrm{mm}$ [29], $10-12.4 \mathrm{~mm}$ [30], $0.15-1 \mathrm{~mm}$ [21], $0.15-$ $4.45 \mathrm{~mm}[31]$, and $9.5-12.5 \mathrm{~mm} \mathrm{[32].}$ 
The type of sand commonly used is type 1 Portland cement. The water to cement ratio used varies from 0.27 to 0.4 . The water to cement ratio of 0.33 performed an ideal permeability and compressive strength for the 10 and $12.5 \mathrm{~mm}$ of sand size [30]. The sand to cement ratio (M) used varies from M 3.7 to M 12.

To get a good PCF, sand, cement, and water that have been weighed according to a specific composition are mixed using the following procedure [33]:

a) $5-10 \%$ of cement mixed with aggregate for one minute.

b) The remaining cement and water are added to the mixture.

c) The mixture is stirred for three minutes, then rested for two minutes, and stirred again for another two minutes.

d) The finished dough is put into the cast by rodding on each layer of dough inserted. After all the dough is put into the cast, vibration is carried out for $5-7$ seconds.

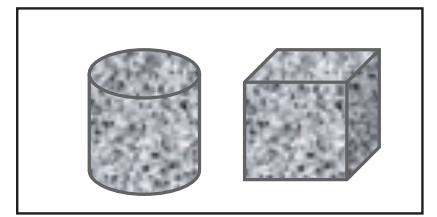

Fig. 2. Cylinders and cubic shape of PCF.

Table 1. Material composition and production of ceramic filter and pervious concrete filter.

\begin{tabular}{|c|c|c|}
\hline Criteria & Ceramic Filter & $\begin{array}{l}\text { Pervious } \\
\text { Concrete Filter }\end{array}$ \\
\hline Material & $\begin{array}{l}\text { Main material = Clay } \\
\text { Combustible material = } \\
\text { sawdust, rice husks, } \\
\text { recycled paper, coffee } \\
\text { husks, peanut husks }\end{array}$ & $\begin{array}{l}\text { Aggregate } \\
\text { (sand), Cement, } \\
\text { Water }\end{array}$ \\
\hline $\begin{array}{l}\text { Size of } \\
\text { material }\end{array}$ & $\begin{array}{l}\text { Clay }( \pm 0.05 \mathrm{~mm} \text { or } 30 \\
\text { mesh) } \\
\text { Combustible material } \\
(35-1000 \text { mesh of } \\
\text { sizes) }(23)\end{array}$ & $\begin{array}{l}\text { Aggregate }= \\
\text { from } 1-2 \mathrm{~mm} \\
(14), 2.36-13.2 \\
\mathrm{~mm}(28), 5-10 \\
\mathrm{~mm}(29), 10- \\
12.4 \mathrm{~mm}(30), \\
0.15-1 \mathrm{~mm} \\
(21), 0.15-4.45 \\
\mathrm{~mm}(31), \text { and } \\
9.5-12.5 \mathrm{~mm} \\
(32) .\end{array}$ \\
\hline $\begin{array}{l}\text { Composit } \\
\text { ion }\end{array}$ & $\begin{array}{l}\text { Clay : Combustible } \\
\text { material } \\
50: 50,65: 35,75: 25 \\
(23)\end{array}$ & $\begin{array}{l}\mathrm{A} / \mathrm{C}=3.7-12 \\
\mathrm{~W} / \mathrm{C}=0.27- \\
0.4(30)\end{array}$ \\
\hline $\begin{array}{l}\text { Productio } \\
\mathrm{n} \text { process }\end{array}$ & $\begin{array}{l}\text { Sieving - Mixing - } \\
\text { Moulding - Air drying } \\
15 \text { days - Firing }(7,26 \text {, } \\
27)\end{array}$ & $\begin{array}{l}\text { Sieving - } \\
\text { Mixing - } \\
\text { Casting - Air } \\
\text { drying } \\
\end{array}$ \\
\hline
\end{tabular}

\subsection{Hydraulic characteristics}

The hydraulic characteristics of PCF studied in this study are porosity and permeability. Porosity is one of the essential factors in determining the performance of $\mathrm{CF}$ and PCF. In PCF, porosity is determined by many factors, including aggregate size, type of aggregate, aggregate gradation, type of cement, aggregate-cement ratio, water-cement ratio, type and dose of admixture, and method of mixing and formation [28]. The main characteristics of pores in pervious concrete include porosity, number of pores, pore size, relationship, pore distribution, and tortuosity [28]. In CF, porosity is determined by the type and size of the combustible material, composition of materials, firing temperature, etc. $[23,34]$.

The porosity of $\mathrm{CF}, \varepsilon$, was measured via water absorption [35] and calculated by Eq. 1 .

$$
\varepsilon=\frac{m_{w} m_{d}}{m_{w} m_{h}}
$$

where $m_{w}$ is the wet mass of CF, $m_{d}$ is the dry mass, and $m_{h}$ is the hydrostatic mass.

The porosity of PCF, $\varphi$, is determined by Eq. 4 [29].

$$
\varphi=1-\frac{\left(w_{2}-w_{1}\right)}{\rho V}
$$

where $w_{2}(\mathrm{~kg})$ is the weight of the oven-dry sample, $w_{1}$ $(\mathrm{kg})$ is the weight of the underwater sample, $\rho\left(\mathrm{kg} / \mathrm{m}^{3}\right)$ is water density at room temperature, and $\mathrm{V}\left(\mathrm{m}^{3}\right)$ is the volume of sample.

Permeability is an essential factor that plays important roles in both CF and PCF. The permeability value describes the filter's ability to drain the water. The permeability is strongly influenced by the pore structure, pore size, and porosity in a filter. The pore structure, size, and distribution of pores in PCF depend on the composition of the material, the aggregate size, the mixing method, and the formation of the concrete filter [28]. Whereas in CF, the pore structure, pore size, and distribution depend on the composition of the material, the type and size of combustible material, the heating temperature, the mixing method, etc [23]

The permeability coefficient of the $\mathrm{CF}, \mathrm{k}$, was calculated from Eq. 1 [35].

$$
k=\frac{Q \mu L}{A \rho g h}
$$

Where $\mathrm{Q}$ is the flow rate of water in CF, $\mu$ is the viscosity of the water, $\mathrm{L}$ is the length or thickness of filter base, $\mathrm{A}$ is the cross-sectional area of the base, $\rho$ is the density of water, $g$ is gravitational constant, and $h$ is the height of water above the base of CF.

The permeability coefficient, $\mathrm{k}$, of the PCF can be calculated using Eq. 4.

$$
k=\frac{\alpha L}{A t} \ln \frac{h_{1}}{h_{2}}
$$

where $k$ is the coefficient of permeability ( $\mathrm{cm} / \mathrm{second}$ ), $\alpha$ is the surface area of the column/chamber $\left(\mathrm{cm}^{2}\right), L$ is the length/height of the porous concrete sample $(\mathrm{cm}), A$ is the area of the porous concrete sample $\left(\mathrm{cm}^{2}\right), h_{l}$ is the initial height of the water $(\mathrm{cm}), h_{2}$ is the final height of the water $(\mathrm{cm})$, and $t$ is the duration of time it takes for the water to descend from the water level $h_{1}$ to $h_{2}$ (seconds). The equation (2) can be used if only the permeability measurement uses the falling head method. The PCF sample is tested in the form of cubes or cylinders.

Through the pores in the CF and PCF filters, water can flow through the filter so that pollutants larger than the pores will be strained on the surface. With a certain pore structure and connectivity in the filter, the pollutants carried by the feed water can be trapped in the pores. 


\subsection{Suspended solid and bacteria}

Total Suspended Solids (TSS) and bacteria are the dominant types of pollutants in the water. Total suspended solids consist of inorganic materials such as sand, silt, and clay. However, bacteria and algae are also often counted as TSS. According to the Soil Science Society of America, and has a size of $2-0.05 \mathrm{~mm}$, silt is $0.05-0.002 \mathrm{~mm}$, and clay is $<0.002 \mathrm{~mm}$. Bacteria and algae have a length between 0.0005 and $0.004 \mathrm{~mm}$ $(0.5-4 \mu \mathrm{m})$ [36]. Inorganic materials and bacteria, algae, and other decomposed organic materials are often found in water. It is necessary to know the concentration of bacteria and TSS in water. Turbidity is one indicator in determining the level of water clarity. The more particles contained in the water, the greater the turbidity value. These particles are not only suspended solids but can also be dissolved solids. Although TSS and turbidity are closely related, turbidity does not directly indicate the TSS value. However, many researchers use the turbidity parameter to determine the level of water clarity as one of the performance indicators of a filter in removing pollutants in water, especially TSS.

\subsection{Effect of material composition on hydraulic characteristics and removal effectiveness}

\subsubsection{Ceramic filter}

Many studies have proven that ceramic filter is userfriendly technology that can effectively reduce contaminants from suspensions to viruses. The high effectiveness of ceramic filters in reducing pollutants is caused by many factors, including clay material, combustible material (composition, type, and size), firing temperature, a surface coating method, and raw water quality.

In CF fabrication, several things need to be considered according to the clay material used, even though it will indirectly affect the removal effectiveness. Some of these things are clay physical properties (shrinkage, plasticity, workability), availability of clay sources, the leachability of heavy metals, and inorganic material. Although clay has no direct effect on the pore structure of CF, many studies have found that different clay sources have various effects on porosity, permeability, and bacterial removal effectiveness.

The combustible material is an essential parameter in determining the removal effectiveness of CF. The types of organic materials used in the manufacture of $\mathrm{CF}$ are usually sawdust $[23,35]$, rice husks, and recycled paper fibres in various forms [7]. The type of combustible material will affect the pore size distribution because of the different shapes of the kind of material.

Moreover, the proportion of clay and the combustible material also affect the porosity and permeability. The use of combustible material, i.e. $20 \%$ and $15 \%$, yields different flow rates and removal effectiveness. When the amount of combustible material is high, namely $20 \%$, the CF flow rate is fast, i.e. 13.9 L/h, with > 2 LRV (> 99\%) for bacterial removal.
Conversely, when the amount of combustible material is reduced to $15 \%$, the flow rates decrease to $5.9 \mathrm{~L} / \mathrm{h}$ with high removal effectiveness reaching $>4 \mathrm{LRV}$ (> $99.99 \%$ ) for bacteria removal [7]. The proportion of clay and combustible material (sawdust) on CF and its effect on hydraulic characteristics was studied by Yakub et al. (2013) [23]. That study analyzed three different proportions (percentage) of clay and sawdust, i.e. 50:50, $65: 35$, and $75: 25$. The results showed that the CF with $50 \%$ of sawdust produced a higher porosity reaching $46 \%$, and achieved $99.99 \%$ of E.Coli bacteria removal or $3.16-8.17$ of $\log$ removal value (LRV). On the contrary, the CF with $35 \%$ of sawdust yields $39 \%$ porosity and $99.99 \%$ of E.Coli bacteria removal or 5.82 -6.9 of LRV. Using the sawdust's size of $35-1,000$ mesh in that experiment, Yakub et al. (2013) found that most of the pore size in that three different compositions were in the range of $0.05-1 \mu \mathrm{m}$ [23]. Nigay et al. (2018) studied the mixture of clay and the three different types of additive i.e. activated carbon as organic material and hydroxyapatite as inorganic material and a mix of both materials. The CF with $20 \%$ of activated carbon produced $52 \%$ porosity and $43 \mathrm{mD}$ of permeability higher than the CF without additive. The CF with $20 \%$ of hydroxyapatite yields $40 \%$ of porosity and $30 \mathrm{mD}$ of permeability. The increased removal of nitrate (organic) and Lead (inorganic) was reached by the CF with $20 \%$ of activated carbon and hydroxyapatite, i.e. 5.7 and 39.5 $\mathrm{mg} / \mathrm{g}$, respectively [19]. The higher the percentage of combustible material, the higher the CF's porosity and permeability $[19,35]$. The porosity, permeability, and pore size distribution will affect the difference in flow rates and removal effectiveness.

Apart from the types and proportion of the combustible material, the size of the material also determines the porosity, pore size, and flow rates. The smaller the material size, the smaller the pore size and flow rate, but the higher is the removal effectiveness. Conversely, the larger the material used, the larger the pore size and leads to an increase in flow rates, which usually reduces the removal effectiveness.

\subsubsection{Pervious concrete filter}

The aggregate size affect the size of the pores in PCF; thus, it also affects the permeability. The larger the aggregate size, the larger the pore size will be. In addition to the aggregate size, the water to cement ratio and the aggregate to cement ratio also affect the permeability and compressive strength of PCF. The greater the water to cement ratio and the smaller the aggregate to cement ratio leads to increased compressive strength and decreased permeability.

Based on the results of a study by Neamitha \& Supraja (2017) and Ali \& Kareem (2014), the best values of the water to cement ratio for pervious concrete are almost the same, i.e. 0.33 and 0.32 , with the aggregate size of $10 \mathrm{~mm}-12.5 \mathrm{~mm}$ and $9.5 \mathrm{~mm}-12.5$ $\mathrm{mm}$ respectively. At low water to cement ratio values, the concrete mixture will be very dry, causing an increase in porosity and permeability. If the value of the water to cement ratio is high, a "drawdown" effect will be formed where water fills the pores of the concrete, 
especially at the bottom part, which results in a decrease in the permeability of the porous concrete $[30,32]$.

The compressive strength is generally inversely proportional to its permeability. This condition is due to the large cement filling the pores, covering each aggregate grain. This condition will strengthen the bonding of each grain, thus increase the compressive strength. On the other hand, it will block pores in pervious concrete to automatically reduce the permeability. Therefore, the amount of cement content and the aggregate to cement ratio are significant in PCF manufacture. The smaller the value of the aggregatecement ratio, the stronger the concrete will be so that the compressive strength will be greater, but the permeability will be more negligible [14]. Unfortunately, the higher the aggregate-cement ratio, the easier the concrete cracks due to the lower compressive strength of PCF.

The composition of materials in the manufacture of PCF is determined based on the purpose of PCF use. Several previous studies have examined pervious concrete as a water filter to remove several pollutants, including turbidity and coliform bacteria. Small aggregate sizes are used for the experiment of pervious concrete as a water filter for suspended solids such as (Triatmadja, 2008) which used an aggregate size of 1 $2 \mathrm{~mm}$ [14], Kamulyan et al. (2011) used an aggregate size of $0.425-0.850 \mathrm{~mm}, 0.850-1 \mathrm{~mm}$, and $1-2 \mathrm{~mm}$ [37], and even smaller if it is used to remove coliform bacteria such as using an aggregate size of $0.15-1 \mathrm{~mm}$ [21]. The size of the aggregate is not the only key to the successful performance of PCF. The aggregate to cement ratio and the water to cement ratio also need to be adjusted and tested to produce pervious concrete that could work appropriately according to its function.

The different ratio of water-cement $(0.24-0.32)$ in the aggregate size of $2.36-12.5 \mathrm{~mm}$ was analyzed by Costa et al. (2021) [38]. With admixture, the lower water to cement ratio $(0.24)$ resulted in a higher porosity, i.e. $28.72 \%$ and permeability, i.e. $2.01 \mathrm{~cm} / \mathrm{s}$. On the other hand, the comparison of with and without admixture on pervious concrete with water to cement ratio of 0.3 found that the pervious concrete without admixture produced a higher porosity, i.e. $26.67 \%$, than that with admixture, i.e. $24.29 \%$. Moreover, the permeability in pervious concrete without admixture was also higher, i.e. $1.7 \mathrm{~cm} / \mathrm{s}$, than that with admixture, i.e. $0.99 \mathrm{~cm} / \mathrm{s}$. The influence of the water to cement ratio on the porosity was also proven quantitatively by the binary image of the pervious concrete surface. The low water to cement ratio presented more interconnected pores than the high one [38].

The influence of aggregate to cement ratio (M) on porosity and permeability was investigated by Zhang et al. (2020) [28]. With the uniform aggregate size, the higher the aggregate to cement ratio, the higher the porosity and permeability of pervious concrete.

The image processing of sliced pervious concrete to investigate the pore structure was conducted by $\mathrm{Ni}$ et al. (2021) [39]. The study analyzed the 2-dimension pore structure of pervious concrete using the software, i.e. Image-Pro Plus (IPP) and Industrial CT scan (scanner machine model XTH320. This study using three different aggregate sizes, i.e. $1.18-2.36 \mathrm{~mm}, 2.36-$ $4.75 \mathrm{~mm}$, and $4.75-9.5 \mathrm{~mm}$. The $\mathrm{M}$ ratios used in this study were M 2.9 to M 4.1. The results showed that the pore sizes ranged $1-3 \mathrm{~mm}, 3-5 \mathrm{~mm}$, and $6-8 \mathrm{~mm}$ for the aggregate sizes of $1.18-2.36 \mathrm{~mm}, 2.36-4.75 \mathrm{~mm}$, and $4.75-9.5 \mathrm{~mm}$, respectively [39]. The image processing shows that the larger the aggregate size, the more significant the large pores formed on the pervious concrete. The higher the $\mathrm{M}$ ratio, the higher the number of pores formed in the pervious concrete.

Pervious concrete can be used as a water and wastewater filter according to its porosity, permeability, pore size, pore connectivity, and material composition. Kim et al. (2017) reported that pervious concrete reduced the concentration of phosphorus and suspended nitrogen by trapping on the pores and the dissolved phosphorus by adsorption [40]. The study conducted by Shabalala et al. (2017) found that the concrete filter was successful in removing the heavy metals ( $\mathrm{Al}, \mathrm{Fe}, \mathrm{Mn}$, $\mathrm{Co}$, and $\mathrm{Ni}$ ) present in the acid mine drainage (AMD) due to the precipitation mechanism and reduce the acidity of AMD due to substitution mechanism [41]. The decrease in Lead $(\mathrm{Pb})$ by pervious concrete was analyzed by Muthu et al. (2018) and found that pervious concrete can remove about $97.2 \%$ to $99.1 \%$ concentration of $\mathrm{Pb}$ in solution [42]. A study conducted by Maadji et al. (2016) found that PCF with composition $\mathrm{M}=4$, the diameter of $10 \mathrm{~cm}$ and height of $20 \mathrm{~cm}$ was able to reduce turbidity to less than 5 NTU and E. Coli bacteria reached $98.71 \%$ or 2 LRV[20,22]. Kamulyan et al. (2012) found that the PCF with $0.425-0.850 \mathrm{~mm}$ aggregate size removed turbidity from the feed water with the effectiveness ranging from $87.8 \%-93.9 \%$ in $0.5 \mathrm{~m} / \mathrm{h}$ of velocity [43]. Velocity affected the removal effectiveness that the slower the velocity of water in $\mathrm{PCF}$, the higher is the turbidity removal effectiveness [44].

\subsection{Removal mechanisms of suspended solids and Bacteria}

According to the hydraulic characteristics (porosity and permeability) and pore size of $\mathrm{CF}$ and $\mathrm{PCF}$, the removal mechanism could vary depending on the size of contaminants in the water. This study investigates the contaminants that probably exist in the water source, i.e. suspended solids and bacteria. The total suspended solids (TSS) consists of particles size larger than two $\mu \mathrm{m}$. Suspended solids usually consist of inorganic materials such as clay, silt, or sand, but organic materials such as plankton and decomposed algae. Bacteria have various sizes, i.e. $\sim 1-3 \mu \mathrm{m}$.

Commonly, the ceramic filter has low permeability. This condition is due to the small size of the pores formed on it. The CF has a pore size ranging from 0.005 - $0.1 \mu \mathrm{m}$ [19] and 0.05 - $1 \mu \mathrm{m}$ [23]. Based on the porosity, pore size, the additive/ composition, and clay structure of the $\mathrm{CF}$, the contaminants, including bacteria, chemicals, and viral, can be removed by several capture mechanisms, i.e. trapping, substitution, and adsorption [35].

In terms of suspended solids, the removal mechanism that may occur in the filter is straining. 
Straining happens when the particle size is larger than the pore size in the filter; for example, the suspended solids (particle size $>2 \mu \mathrm{m}$ ) are retained in the surface of CF (pore size $\sim 0.005 \mu \mathrm{m}-1 \mu \mathrm{m}$ ) [45]. A smaller particle such as bacteria $(\sim 1 \mu \mathrm{m}-3 \mu \mathrm{m})$ may pass the pores on the surface of CF. However, the pores may trap the bacteria due to wide ranges of pore sizes from nanoscale pores to micro-scale pores and pore structure on the $\mathrm{CF}$.

The removal mechanisms of suspended solids and bacteria in PCF were also controlled by the hydraulic characteristics especially pore size and pore connectivity. The previous studies found that, generally, the pore size of PCF was larger than that of $\mathrm{CF}$. These pores characteristics affect the permeability value of the PCF, where the PCF permeability value is greater than the CF permeability.

Suspended solids can be removed from the PCF by a straining mechanism based on the pore size and pore connectivity. Suspended solids will be trapped and stuck in the deadlocked pores. Bacteria may be removed from the feed water if the dirty layer formed on the PCF. The dirty layer will then capture the bacteria, thereby reducing the number of bacteria in the outlet. Bacteria will also trap in the tiny pores formed in the PCF. However, to improve the effectiveness in bacteria removal, the PCF needs to be made using a small aggregate size, i.e. less than $\sim 1 \mathrm{~mm}$ with appropriate proportions of cement, aggregate, and water.

\section{Conclusion}

Ceramic filter mostly consists of clay and combustible material such as sawdust. In some cases, the addition of organic (such as activated carbon) and inorganic (such as hydroxyapatite) to the ceramic was objected to improve the removal effectiveness. The type, mineral, and sources of clay and the type, shape, proportion, and size of combustible materials will affect its hydraulic characteristic (porosity, permeability, pore size, pore structure, pore connectivity/ distribution). The larger the size of combustible material, the larger the proportion of large pores formed in $\mathrm{CF}$, thus increasing the porosity and permeability. The greater proportion of combustible material, the greater is the porosity and the permeability of the ceramic filter. The higher porosity and permeability, the smaller is the effectiveness of CF in reducing the contaminant.

The pervious concrete filter consists of aggregate, cement, and water. The addition of additive and admixture was sometimes added to improve the mechanical strength and performance of PCF in removing the contaminants. The shape, size, and type of aggregate, the ratio of water to cement, and the ratio of aggregate to cement will affect its hydraulic characteristics (porosity, permeability, pore size, pore structure, pore connectivity/ distribution). The larger the aggregate size, the larger the proportion of large pores formed in PCF, increasing the porosity and permeability of PCF and decreasing the ability to remove the smallsized contaminants. The smaller the aggregate to cement ratio, the smaller the pore size formed in the PCF. By forming connected, semi-connected, and closed pores in the PCF, the contaminants can be removed according to the contaminant size.

The removal mechanisms of suspended solids and bacteria for CF and PCF are similar to the same "cast type" filter. The pores are the main feature in those two filters that retain the contaminants, especially those larger than $1 \mu \mathrm{m}$. The removal mechanisms of suspended solids ( $>2 \mu \mathrm{m}$ of size) are straining on the surface and trapping on the deadlocked pores. On the other hand, the bacteria $(\sim 1-3 \mu \mathrm{m}$ of size) removal is straining in the dirty layer and trapping the bacteria in the pores.

So far there is no information regarding the performance of PCF constructed with combined value of composition (M) in stages. In real aplication such stages of PCF element of different value of M could probably be used to enhace the capacity of trapping or straining the contaminant depending on their sizes. This may prolonge the use of the PCF before it has to be backwashed.

The authors are thankful for the financial support given by The Indonesia Endowment Fund for Education (LPDP) through the scheme of Beasiswa Pendidik 2020.

\section{References}

1. World Health Organization, World Health Statistics 2020: Monitoring Health for The SDGs (2020)

2. A. Battilani, M. Steiner, M. Andersen, S. N. Back, J. Lorenzen, A. Schweitzer, A. Dalsgaard, A. Forslund, S. Gola, W. Klopmann, F. Plauborg, and M. N. Andersen, Agric. Water Manag. 98, $385(2010)$

3. C. K. Pooi and H. Y. Ng, Npj Clean Water 1, (2018)

4. United Stades of America, US Environ. Prot. Agency EPA 815 (2006)

5. F. Klingel and S. Diener, Guidebook for the Implementation of Decentralised Water Supply Systems in Moldova (Skat Consulting Ltd, Moldova, 2014)

6. Sustainable Infrastructure Society, Guide Book : Planning and Implementation of " Point of Entry " and "Point of Use" Water Treatment Systems in British Columbia (2007)

7. H. Yang, S. Xu, D. E. Chitwood, and Y. Wang, Front. Environ. Sci. Eng. 14, 1 (2020)

8. Joseph Mark Brown, Effectiveness of Ceramic Filtration for Drinking Water Treatment in Cambodia (2007)

9. D. Xu, L. Bai, X. Tang, D. Niu, X. Luo, X. Zhu, G. Li, and H. Liang, Sci. Total Environ. 691, 322 (2019)

10. A. Silva and S. Fuchs, (2015)

11. G. S. Logsdon, R. Kohne, S. Abel, and S. LaBonde, J. Environ. Eng. Sci. 1, 339 (2002)

12. E. Yogafanny, S. Fuchs, and U. Obst, J. Sains \&Teknologi Lingkung. 6, 107 (2014)

13. J. F. Schijven, H. H. J. L. Van den Berg, M. Colin, Y. Dullemont, W. a. M. Hijnen, A. Magic- 
Knezev, W. a. Oorthuizen, and G. Wubbels, Water Res. 47, 2592 (2013)

14. R. Triatmadja, 2008, 1 (2008)

15. H. Zhang and V. Oyanedel-Craver, J. Hazard. Mater. 260, 272 (2013)

16. A. R. Bielefeldt, K. Kowalski, and R. S. Summers, Water Res. 43, 3559 (2009)

17. M. Y. M. Soliman, D. van Halem, and G. Medema, Int. J. Hyg. Environ. Health 224, (2020)

18. A. R. Bielefeldt, K. Kowalski, C. Schilling, S. Schreier, A. Kohler, and R. S. Summers, Water Res. 44, 1482 (2010)

19. P. Nigay, A. Nzihou, C. E. White, and W. O. Soboyejo, 144, 1 (2018)

20. R. Maadji, R. Triatmadja, and F. Nurrochmad, in Proc. 37th IAHR World Congr. (2017), pp. 27052713

21. R. Maadji, R. Triatmadja, F. Nurrochmad, and Sunjoto, in Proc. Second IAHS Panta Rhei Int. Conf. Water Syst. Knowl. Innov. Its Pract. Dev. Ctries. (2017), p. 44

22. R. Maadji, R. Triatmadja, F. Nurrochmad, and Sunjoto, in Proc. Int. Semin. Water Resil. a Chang. World (2016), pp. 711-721

23. I. Yakub, D. Ph, A. Plappally, D. Ph, M. Leftwich, D. Ph, K. Malatesta, D. Ph, K. C. Friedman, S. Obwoya, D. Ph, F. Nyongesa, D. Ph, A. H. Maiga, D. Ph, M. Asce, A. B. O. Soboyejo, D. Ph, S. Logothetis, W. Soboyejo, and D. Ph, 08544, 986 (2013)

24. J. Rayner, Current Practices in Manufacturing of Ceramic Pot Filters for Water Treatment, 2009

25. U. E. Ekpunobi, S. U. Agbo, and V. I. E. Ajiwe, J. Environ. Chem. Eng. 7, 102791 (2019)

26. H. Yang, Z. Yan, X. Du, L. Bai, H. Yu, A. Ding, G. Li, H. Liang, and T. M. Aminabhavi, Chem. Eng. J. 382, 123033 (2020)

27. E. A. Zereffa and T. B. Bekalo, Mater. Sci. Appl. Chem. 34, 69 (2017)

28. Y. Zhang, H. Li, A. Abdelhady, and J. Yang, Constr. Build. Mater. 263, 120614 (2020)

29. Y. Qin, H. Yang, Z. Deng, and J. He, Adv. Mater. Sci. Eng. 2015, 1 (2015)

30. M. Neamitha and T. M. Supraja, Int. Ref. J. Eng. Sci. ISSN 6, 2319 (2017)

31. M. M. Taghizadeh, a. Torabian, M. Borghei, and a. H. Hassani, Int. J. Environ. Sci. Technol. 4, 505 (2007)

32. M. K. Ali and Q. M. S. Kareem, Int. Jourbal Enhanc. Res. Sci. Technol. Eng. 3, Issue 1, 107 (2014)

33. K. Wang, V. R. Schaefer, J. T. Kevern, and M. T. M. M. T. Suleiman, NRMCA Technol. Forum Focus Pervious Concr. 1 (2006)

34. P. M. Nigay, A. A. Salifu, J. D. Obayemi, C. E. White, A. Nzihou, and W. O. Soboyejo, 146, 1 (2020)

35. P. Nigay, A. A. Salifu, J. D. Obayemi, C. E. White, A. Nzihou, and W. O. Soboyejo, 145, 1 (2019)

36. W. J. Rogan, M. T. Brady, H. J. Binns, J. a. Forman, C. J. Karr, K. Osterhoudt, J. a. Paulson, J. R. Roberts, M. T. Sandel, J. M. Seltzer, R. O.
Wright, E. Blackburn, M. Anderson, S. Savage, N. B. Ragan, P. Spire, J. a. Bocchini, H. H. Bernstein, J. S. Bradley, C. L. Byington, P. H. Dennehy, M. C. Fisher, R. W. Frenck, M. P. Glode, H. L. Keyserling, D. W. Kimberlin, W. a. Orenstein, L. G. Rubin, R. S. Baltimore, J. a. McMillan, B. Bell, R. Bortolussi, R. D. Clover, M. a. Fischer, R. L. Gorman, R. D. Pratt, J. S. Read, B. Gellin, J. R. Starke, J. Swanson, C. J. Baker, S. S. Long, L. K. Pickering, E. O. Ledbetter, H. C. Meissner, and J. Frantz, Drinking Water from Private Wells and Risks to Children (2009)

37. B. Kamulyan, F. Nurrochmad, R. Triatmadja, and Sunjoto, in 4th ASEAN Environ. Eng. Conf. (2011)

38. F. B. Pereira da Costa, L. M. Haselbach, and L. C. P. da Silva Filho, Constr. Build. Mater. 268, 121084 (2021)

39. T. Ni, W. Ma, Y. Yang, J. Yu, J. Liu, C. Jiang, and C. Gu, Constr. Build. Mater. 267, 121052 (2021)

40. G. M. Kim, J. G. Jang, H. R. Khalid, and H. K. Lee, Constr. Build. Mater. 136, 1 (2017)

41. A. N. Shabalala, S. O. Ekolu, S. Diop, and F. Solomon, J. Hazard. Mater. 323, 641 (2017)

42. M. Muthu, M. Santhanam, and M. Kumar, Constr. Build. Mater. 174, 224 (2018)

43. B. Kamulyan, F. Nurrochmad, and R. Triatmadja, in Annu. Eng. Semin. "Towards Sustain. Eng. (2012)

44. B. Kamulyan, F. Nurrochmad, R. Triatmadja, and S. Sunjoto, in Int. Conf. Sustain. Dev. Water Wastewater Treat. (Yogyakarta, Indonesia, 2009)

45. S. a. Bradford, J. Simunek, M. Bettahar, M. T. Van Genuchten, and S. R. Yates, Environ. Sci. Technol. 37, 2242 (2003) 